\title{
The Role of School Committees in Improving the Quality of Education at Muhammadiyah Islamic Elementary School Blangpidie Aceh Indonesia
}

\author{
Baidullah \\ Secretary of Krueng Semayam Village \\ Nagan Raya Regency, Aceh, Indonesia \\ niswanto@fkip.unsyiah.ac.id
}

\author{
Niswanto \\ Department of Educational Administration \\ Syiah Kuala University, Indonesia \\ niswanto@ fkip.unsyiah.ac.id
}

\author{
Nasir Usman \\ Department of Educational Administration \\ Syiah Kuala University, Indonesia \\ niswanto@ fkip.unsyiah.ac.id
}

\begin{abstract}
The purpose of this study is to find out the extent of the school committee's role in improving education quality at Muhammadiyah Islamic Elementary School of Blangpidie. The design of this research is descriptive qualitative research, which is a qualitative research. The method to obtain the data is observation, interview, documentation, and triangulation. Technique of data analysis in this study uses data reduction, data visualization, drawing conclusions and data verification. The subjects of this study are School Committee and Principal of Muhammadiyah Islamic Elementary School of Blangpidie. Based on the study results, it is found that (1) The school committee programs in improving the quality of education at Muhammadiyah Islamic Elementary School has been arranged but not well documented. (2) The implementation of the school committee programs in improving the quality of education at Muhammadiyah Islamic Elementary School has run very well. (3) The obstacles faced by school committee in implementing the program at Muhammadiyah Islamic Elementary School of Blangpidie, most of the school committee members are sluggish because of their busy life.
\end{abstract}

Keywords: school committee, education quality

\section{INTRODUCTION}

Administering education needs to pay attention to quality improvement from time to time. Quality is a big picture and characteristics of goods or services that show their ability to satisfy the expected or implied needs (Rohiat, 2012). In the context of education, understanding the quality includes input, process, and education output. The quality of education consists of academic quality and non-academic quality (Kholis et al., 2014). Both of these quality aspects can be seen from the school level and learning level.

The quality of education in Aceh if linked to human development index (HDI) every year shows a trend of progress and improvement. According to the 2017 Central Statistics Agency's report, the province's HDI in 2016 has a high status compared to the 20102015 period with medium status. Meanwhile, the HDI of Nagan Raya Regency and Southwest Aceh Regency is currently not in line with the improvement of the HDI of Aceh province, whereas the HDI of Nagan Raya Regency and Southwest Aceh Regency are classified as medium.

The HDI status can also illustrate that the quality of the education sector in Nagan Raya and Southwest Aceh still raises serious attention from all stakeholders. Stakeholders in education sector can come from school's internal or external. Internal stakeholders are those in a school which consists of teachers, staff, and school committees, while external stakeholders are those who are from outside the school consisting of student's parents/guardians (Krisnayanti, 2014). The actor of quality school development and stakeholder's participation culture are the principal which focuses on developing the potentials owned by internal and external stakeholders by providing space and attitude that is conducive to the growth of intrinsic motivation (Kholis et al., 2014).

The participation of internal stakeholders, especially school committees, holds a very important influence on improving the quality of school education. School committees act as an advisory agency, supporting agency, controlling agency and mediatory agency between the government and the community in education units (Misbah, 2009). The results research Mulyono (2014) on the comparison of the role of school committees at public and private vocational high school yields good results, but there are discrepancies on the role of the school's highest committee in which at public vocational high schools, the highest role of the school's committee is an Advisory Council, while at private vocational high schools, the highest role of the school committee is as a supporting council.

In this study, the researcher seeks to dig more information about the role of committee at the research site. As we know that the committee plays an important role in school development. Regarding the size of the school committee's role in improving the quality of education and related to the level of education in Southwest Aceh Regency that needs serious attention, it is necessary to conduct a deeper study on the role of the school committee in enhancing the quality of education at Muhammadiyah Islamic Elementary School of Blangpidie. The purpose of this study is to determine the extent of the school committee's role in bettering the Quality of Education at Muhammadiyah Islamic Elementary School of Blangpidie. 


\section{METHODS}

This study uses descriptive qualitative method which is a type of qualitative research. Qualitative research is also called naturalistic research. It is called qualitative because the nature of the data collected is qualitative pattern rather than quantitative because it does not use measuring instruments (Rahmat, 2012). It is called naturalistic because the field situation of the research is natural or as it reasanable, without manipulation, experiment, or test. The study was conducted at Muhammadiyah Islamic Elementary School of Blangpidie, Southwest Aceh Regency.

This study is planned to begin from April to March 2018. The subject of this study is the Principal and School Committee. This study uses the researcher as an instrument. Data collection on the role of the School Committee in Improving the Quality of Education at school through Observation, Interview, Documentation and, Triangulation is by asking questions that have been designed in accordance with the research objectives. In this study, the researcher carries out two phases of data analysis, the first is data analysis before the research in the field and the second is by employing Milles and Huberman qualitative data analysis, which includes: (1) data reduction; (2) data display/ data visualization; and (3) drawing conclusions and be verified.

\section{RESULTS AND DISCUSSION}

By analyzing the results of the above research, the writer seeks to provide a discussion by presenting a connection with experts' opinions. To clarify the discussion about the role of the school committee in improving the quality of education at Muhammadiyah Islamic Elementary School of Blangpidie, here are some explanations:

\section{School Committee Program in Improving Education Quality at Muhammadiyah Islamic Elementary School of Blangpidie}

The school committee plans and prepares programs in proportion to the needs of the school. It encourages the growth of attention and commitment of the community towards the implementation of quality education. In addition, it cooperates with the community and schools regarding the application of quality education, accommodates and analyzes aspirations, ideas, demands, and various educational needs requested by the community (students' parents). Moreover, it also provides input, consideration, and recommendations regarding Education Policy and Program, School Budget Plan, concerning the source of funds from students' parents.

Furthermore, criteria of education facilities as well as other matters related to the development of education. The school committee communicates with the community so that the community can offer inputs and donations in various forms for the development of education in the school. The school committee is a school partner in the development of school education in order to fulfill high quality education. Satori states that community participation through school committees must also be directed to creating new institutional cultures in school management (Sagala, 2017), namely:

a. The school committee is a school partner that jointly strives for the development of schools.

b. Developing the school's strategic plans by devising school's priority programs, school's goals, target achievement strategies, control of achievement and evaluation of attainments of the school's targets.

c. Developing school's yearly plans.

d. Conducting internal monitoring and regular selfevaluation, as well as reporting and discussing the outcomes at the school committee forum.

e. Preparing the school annual report that describes the implementation of the school's annual planning. The annual school report is discussed in the forum and must be approved by school committee.

f. Organizing school review, this action is very useful to find out the objective conditions of each school within a coaching zone.

g. Conducting a survey on school opinions on school stakeholders.

h. Organizing "open days" for parents and the community, so they have a better understanding of the internal life of the school.

i. Monitoring school's performance which includes school management performance, principal leadership, quality of teaching and learning including teacher's teaching performance, student learning outcomes, school's discipline and code of conduct, school's accomplishments, both from intra and extra-curricular aspects.

Building good and high-quality education is not an easy task. It requires collaboration from all levels of society and school committees. Schools are a shared responsibility of all social classes, this is because the society is not only the users of education, but also the benefit recipient of schools. The good quality or poor quality of the school strongly depends on the role of the community through the school committee.

The Program Implementation of the School Committee in Improving the Quality of Education at Muhammadiyah Islamic Elementary School of Blangpidie

Ever since the launch of the concept of Management of School-Based Quality Improvement in the school management system, the School Committee as a school partner organization has a very strategic role in an effort to participate in developing education at schools. Its presence should become an organization that can truly accommodate and channel the aspirations and initiatives from the community in producing operational policies and education programs at schools and can create a transparent, accountable, and democratic atmosphere in the administering high quality education services at schools. The School Committee is formed based on the mandate of Law Number 25 of 2000 concerning the National Development Program.

School Committee is formed in each education unit or group of education units. The existence of the 
School Committee has now been strengthened from the legal aspect because it has been included under the Law Number 20 of 2003 concerning the National Education System, namely Article 56. The School Committee was formed so that there was a community organization that have commitment and loyalty and care for the improvement of school quality. The established School Committees can be developed specifically and find roots in culture, demographics, ecology, agreements value that grow and develop within the community itself".

Therefore, the building up of School committee program must be a developer of the philosophical assets of the community collectively. As a result, the School Committee develops user-oriented concepts, shares authority and partnerships that are focused on improving the quality of education. School committees that have been founded must always improve their abilities and responsibilities. Thus, the community and the government always carry out the empowerment of the School Committee. The government is obliged to carry out the empowerment, such as by conducting trainings.

The school committee makes use of its functions in school planning ranging from curriculum preparation, School Activity and Budget Plans and evaluation of teaching staff. In playing their roles, School committee always adjusts itself with school conditions and needs. Then school committees are also harmonious with the school's vision and mission and actively communicate with the principal regarding teaching staff and other things related to education. Sagala (2017) states the role of school committees is not limited to mobilizing donations, but contributing to more substantive matters such as giving input to school planning and overseeing the implementation of education.

Sagala (2017) states the school committee's contribution to schools are as follows: (1) designing and preparing the school strategic plan; (2) composing the school annual planning; (3) holding scheduled meetings to discuss various things about school; (4) thinking about possible efforts to improve the school; (5) encouraging the schools to conduct internal monitoring; (6) discussing the results of standardized tests conducted by external institutions; and (7) discussing the school's annual report so as to obtain a precise picture over the reception of school committee.

If you look at the explanation above, the things that have been done by Muhammadiyah's Islamic elementary school have gone as expected. This should be continued so that all people have a sense of responsibility in the development and improvement of education quality. In assisting the school administration, the committee of Muhammadiyah Islamic elementary school also played a role in the determination of monthly school fees. This is to maintain transparency to the students' guardians and to explain them about the usage of the school's monthly fee. Community involvement is measured by the participation of the community in paying the fees that fall into the category of development assistance, known as Education Donation Fund and students' monthly fee (Sagala, 2017).

Universally applicable participation is a close cooperation between the school and the community around the school in devising strategic plans, implementing, preserving, and developing the quality of schools. Muhammadiyah Islamic Elementary School of Blangpidie is a private school where much of the school's operations are imposed on student financial contributions. Just like what you see in the above explanation that student's contributions greatly help Muhammadiyah Islamic Elementary School of Blangpidie in conducting its school operations.

The school committee of Muhammadiyah Islamic Elementary School of Blangpidie also plays a part in complementing its facilities. The role of school committees in the procurement of facilities is very imperative, because with the availability of good facilities, learning activities can run optimally (Nurhikmayanti, et.al (2014). The decree of the minister of education and culture, number 75 of 2017 school committees can raise funds and other education resources to carry out their functions in providing personnel support, facilities, and education supervision. In accordance with the explanation above, the committee's role at Muhammadiyah Islamic Elementary School of Blangpidie needs to be applied continuously considering that education facilities are an important part in improving the quality of education at Muhammadiyah Islamic Elementary School of Blangpidie compliant with what is planned in the school curriculum.

The quality of education is the goal of every school. To achieve the appropriate education quality, it is necessary to carry out the missions as planned. The quality of education consists of academic quality and non-academic quality (Kholis et al., 2014). Both of these quality aspects can be seen from the school level and learning level. To achieve good quality, careful planning is indispensable in every school. Educational planning is between two parts, namely one plan plays a role to provide various things that are needed by the schooling system and the other plan is seeks to find policymakers, all parties who can help make education policies that education planners must put into practice (Martin, 2013).

Every school ought to include all aspects of the school planning process to achieve good quality education. The principal and the school committee work hand in hand in building school education. Today, the quality of education is a concern for the community. It will become a serious problem in education regardless of its education quality. While in the National Education Standards Board, it has been set clearly regarding national education standards, namely The National Education Standards consist of: (1) graduates competency standards; (2) content standards; (3) process standards; (4) education standards and education personnel; (5) standards of facilities and infrastructure; (6) management standards; (7) education financing standards; and (8) educational assessment standards. 
If you look at the explanation above, in order to achieve the good quality, the involvement of all parties in the school, principal, teachers, students and students; guardians through the school committee are vital. It is imperative to invite and persuade all parties, because the school's budget is very limited and it does not meet the standard of adequate facilities at school. To assist the availability of school facilities, the role of the committee is needed to raise nonbinding funds from external parties. If the school committee is unable to carry out its functions and role, it will directly affect the quality and quantity of the school's education. Insufficient school facilities can affect the quality the school itself eventually.

\section{CONCLUSIONS}

The school committee program in improving the quality of education at Muhammadiyah Islamic Elementary School of Blangpidie has been arranged but has not been properly documented. The implementation of the school committee program in improving the Quality of Education at Muhammadiyah Islamic Elementary School of Blangpidie has run relatively well. The obstacle faced by the school committee in the application of the school committee program at Muhammadiyah Islamic Elementary School of Blangpidie is that most administrators of school committee are less active due to their personal activities.

\section{REFERENCES}

[1] Central Bureau of Statistics of Aceh in 2017. Statistics Official Bulletin. 23/05/XX, May 5, 2017.

[2] Indonesian Law Number 20 of 2003 Concerning the National Education System. 2009. Jakarta: Sinar Grafika.

[3] Kholis, N. Z., and Sumarno. 2014. School Quality and Culture of Stakeholders Participation. Journal of Educational Development, Foundation and Application, 2(2), 141-149.

[4] Krisnayanti, I. A. P. A. 2014. Analysis of Stakeholders' Perceptions Internally and Externally towards Transparency and Accountability of the Management on the Financial Statements of School Operational Assistance at Junior High School 1 of Banjar in 2013. Retrieved October 16, 2017, from https://media.neliti.com/media/publications/5340-IDanalisis-persepsi- stakeholder-internal-dan-eksternalterhadap-transparansi-dan-a.pdf.

[5] Matin. 2014. Educational Planning. Jakarta: Raja Grafindo Persada.

[6] Mayarani, S., and Nurhikmayati, D. 2014. The Role of School Committees in Procurement of Facilities and Infrastructure at Public Elementary School 4 Pucang of Sidoarjo. Journal of Education Management and Aspiration, 4(4), 1-10.

[7] Muliyono. W. D., and Pardjono. 2014. The Role of School Committees in Education Administration at Vocational High School in Lamongan, East Java. Journal of Vocational Education, 4(3), 392-399.

[8] Rahmad, A. 2016. Management of School Public Relations. Retrieved October 16, 2017, from http://repository.ung.ac.id/get/kms/9343/ManajemenHumas-Sekolah.pdf.
[9] Rahmat. S. P. 2012. Qualitative Research. Retrieved October 16, 2017, from https//yusuf.staff. ub.ac.id/files/2012/11/Jurnal-Penelitian-Kualitatif.pdf.

[10] Rohiat. 2012. School Management. Bandung: PT Refika Aditama.

[11] Sagala. S. 2017. Strategic Management in Improving Education Quality. Bandung: Alfabeta. 